\title{
Frequency of L1721W Polymorphism in TET2 Gene Among a Cohort of Sudanese Patients with Myeloproliferative Disorders: Possible Roles in Pathogenicity and Leukemic Transformation
}

\author{
Anas Abdelrahman Ibrahim, ", Eltahir Awad Gasim Khalil ${ }^{2}$ \\ ${ }^{1}$ Department of Hematology \& Immunohematology, Faculty of Medical Laboratory Sciences, Omdurman Islamic University, Khartoum, \\ Sudan \\ ${ }^{2}$ Department of Clinical Pathology \& Immunology, Institute of Endemic Diseases, University of Khartoum, Khartoum, Sudan
}

\author{
Email address: \\ Anas_elzein@yahoo.com (A. A. Ibrahim) \\ ${ }^{*}$ Corresponding author
}

\section{To cite this article:}

Anas Abdelrahman Ibrahim, Eltahir Awad Gasim Khalil. Frequency of $L 1721$ W Polymorphism in TET2 Gene Among a Cohort of Sudanese Patients with Myeloproliferative Disorders: Possible Roles in Pathogenicity and Leukemic Transformation. International Journal of Genetics and Genomics. Vol. 5, No. 5, 2017, pp. 49-53. doi: 10.11648/j.ijgg.20170505.11

Received: February 27, 2017; Accepted: April 21, 2017; Published: October 18, 2017

\begin{abstract}
Transformation of myeloproliferative disorders (MPDs) to acute leukemia is an evitable event that represents a stumbling block in the management of patients. The Janus Kinase-2 JAK2V617F mutation of MDP does not clarify the phenotypic variability observed in this disorder. But, a mutations in Ten-eleven-translocation-2 (TET2), a putative tumor suppressor gene, was recently implicated in MPDs and other hematologic malignancies. TET-2 is believed to play a role in leukemic transformation. This study aimed to determine the frequency of L1721W polymorphism in TET2 gene in a cohort of Sudanese patients with MPDs. Following informed consent, $25(25 / 50,50 \%)$ patients with polycythemia rubra vera (PRV), thirteen patients $(13 / 50,26 \%)$ with essential thrombocythemia (ET), eleven patients $(11 / 50,22 \%)$ with chronic myeloid leukemia (CML), and one patient (1/50,2\%) with primary myelofibrosis (PMF) were enrolled. None of the patients was in the transformation phase. Patients were diagnosed based on clinical picture, hematological parameters and JAK2V617F and $B C R \_A B L$ molecular aberrations. $J A K 2 V 617 F$ was detected in Ph-negative-MPDs cases as (24/25, 96\%) in PRV, $(10 / 13,76 \%)$ in ET, and $(1 / 1,100 \%)$ in PMF. $B C R \_A B L$ fusion was detected in all $(11 / 11,100 \%)$ cases of CML. DNA was extracted using the guanidine chloride method, followed by (PCR-RFLP) analysis. Only one patient showed the presence of L1721W polymorphism of the TET2. It was inferred that the low frequency of this transformation within the study cohort [all in chronic phase] probably indicates that it plays a minor role in MPD pathogenesis, while its role in blast transformation needs further studies in MPD patients.
\end{abstract}

Keywords: Myeloproliferative Disorders, L1721W Polymorphism in TET2 Gene, Sudanese Patients

\section{Introduction}

The classical myeloproliferative disorders (MPDs) comprise polycythemia rubra vera (PRV), essential thrombocythemia (ET) and primary myelofibrosis (PMF) [1].They were originally grouped together by Dameshek along with chronic myeloid leukemia (CML) in 1951 [1].After the discovery of the Philadelphia ( $\mathrm{Ph})$ chromosome, which is characteristic of CML, PV, ET and PMF became recognized as the Ph-negative MPDs [2].The World Health Organization groups the MPDs along with CML and rarer clonal disorders including chronic neutrophilic leukemia (CNL), chronic eosinophilic leukemia (CEL) and clonal mast cell diseases $(\mathrm{MCD})$ under the heading of myeloproliferative disorders [1].

These disorders share many features, including altered stem cell behavior, overproduction of myeloid lineages and rarely, transformation to acute myeloid leukemia (secondaryAML) which reveals different cytogenetic changes and prognoses $[3,4]$.They share substantial phenotypic mimicry, can undergo phenotypic shifts (from PRV to ET and vice versa) as well as evolution to myelofibrosis (post- PRV/post- 
ET myelofibrosis), and all eventually progress to leukemia. The discovery of mutations activating JAK-STAT signaling in the majority of patients with MPDs led to identification of tyrosine kinase activation as a predominant mechanism driving MPD pathogenesis [5, 6]. Despite this, the existence of additional genetic events that modify the MPD phenotype, predate JanuseKinase-2 (JAK2) mutations, and/or contribute to leukemic transformation of MPDs has been suggested. Recently, mutations in several epigenetic modifiers have been described in patients with MPDs, including mutations in TET2 [7].

TET2 [ten-eleven-translocation-2], is a member of a family that includes also TET1 and TET3. TET2 is located on 4q24 and contains 11 exons [8].Enzymes of the TET family are deoxygenizes that convert 5-methylcytosine $(5 \mathrm{mC})$ to 5 hydroxymethylcytosine $(5 \mathrm{hmC})$ and the further oxidation products 5-formylcytosine (5fC) and 5-carboxylcytosine $(5 \mathrm{caC})$ [9]. Together these oxidized methylcytosines (oxi$\mathrm{mC}$ ) facilitate DNA demethylation and also function as epigenetic markers [9-11].

Delhommeau et al., showed that TET2 defects target both multi-potent and committed progenitors and were associated with a selective advantage of early hematopoiesis [12]. TET loss-of-function accelerates myeloid leukemogenesis, through mechanisms that involve lineage dys-regulation, uncontrolled expansion and genomic instability in differentiating cells in mice, pointing to a causative role for TET loss-of function in this myeloid malignancy [13]. Missense L1721W polymorphism in TET2 gene located in exon 11, causes an amino acid change from leucine to tryptophan through substitution of thymine to guanine nucleotide $(\mathrm{T}>\mathrm{G})$. L1721W has been associated with different myeloid related disorders $[14,15,16]$.The SIFT and Polyphen tools predict the variation effect on protein function based on sequence homology and the physio-chemical similarity between the alternate amino acids, it appear deleterious (SIFT) and possibly damaging (Polyphen).

This study aims to determine the frequency of L1721W polymorphism in TET2 gene in cohort of Sudanese patients with MPDs. The study also aims to infer the role of these polymorphs in the pathogenesis of MPD.

\section{Materials and Methods}

\subsection{Patients}

After approval of the study protocol by the Institutional Research Ethics Committee, fifty samples with clinical, hematological and molecular diagnosis of MPD were included in the study. Patients came to a hematological referral center in Khartoum [Zahrawi Medical Laboratories]. The center consents patients to use the reminder of their routine samples for further future investigations/research, those who abstain will have their samples destroyed. 25 $(25 / 50,50 \%)$ patients with polycythemia rubra vera (PRV), thirteen patients $(13 / 50,26 \%)$ with essential thrombocythemia (ET), eleven patients $(11 / 50,22 \%)$ with chronic myeloid leukemia (CML), and one patient (1/50, 2\%) with primary myelofibrosis (PMF) were enrolled.

\subsection{Molecular Biology}

Diagnosis of MPD were established on the basis of the WHO 2008 diagnostic criteria [17, 18].The JAK2V617F status and $\mathrm{Ph}$ ' chromosome study was determined prior to the study as part of routine diagnostic testing according to previously published methods [19, 20].Genomic DNA was extracted from peripheral blood granulocytes using guanidine chloride method [18]. The concentration and purity of genomic DNA was tested using the Nanodrop machine (implen $\mathrm{GmbH}$, Germany).A high fidelity Polymerase Chain Reaction (PCR)was used in the amplification steps with standard conditions using Maxime PCR preMix kit ( $i$-Taq for $20 \mu \mathrm{rxn})$ with sequence specific primers of TET2 gene F(5'-CTCCCCATATTGGGTTCCT-3') and R (5'CCCATTAGCTGTGTGGGAAA-3'). The primer were designed for specific sequence in exon 11 to amplify $463 \mathrm{bp}$ amplicons, using the online primer design program Primer3Plus (Untergasser and Nijveen 2007) using the NC_000004.11 reference sequence obtained from the National Centre for Biotechnology Information (NCBI) database, and manufactured by Inqababiotec, South Africa. The PCR amplification was performed in a programmable thermal cycler (ESCO, Aeris ${ }^{\mathrm{TM}}$ thermal cycler 96, Singapore) at Annealing temperature adjusted to $62^{\circ} \mathrm{C}$. After completion of the PCR reaction, gel electrophoresis was performed to confirm the presence of the correct bands size. PCR products were resolved on an ethidium bromide $(1.5 \mu \mathrm{l})$ stained $1.2 \%$ agarose gel. The gel was run at $100 \mathrm{~V}$ for approximately 40 minutes. A molecular weight marker (Thermo Scientific 50 bp DNA ladder, USA) was also resolved on the gel to confirm the fragment size of the PCR products. Afterwards, the gel was visualized under UV light with the UV Transilluminator (UV Transilluminator MUV series, Major science, Taiwan). PCR-restriction fragment polymorphism was done by digesting the PCR products with HaeIII restriction enzyme and its buffer for 1 hour at $37^{\circ} \mathrm{C}$. The restriction products were resolved in a $3 \%$ agarose gel, and then visualized under UV light with the UV transilluminator. HaeIII digests wild-type (wt) allele to two fragments, with sizes $267 \mathrm{bp}$ and $196 \mathrm{bp}$, while the mutated allele creates a de novo HaeIII digestion site in given sequence, allow mutant allele to be digested by HaeIII to three fragments, with sizes $230 \mathrm{bp}, 196 \mathrm{bp}$, and $37 \mathrm{bp}$.

\subsection{Statistical Analysis}

Statistical analyses were performed using Epi Info ${ }^{\mathrm{TM}} 7$. Categorical variables were described as frequencies and percentages.

\section{Results}

Samples from females and males were included in this study (Table 1). Their ages range from 32-75 years 
(Mean \pm SD: $52.1 \pm 9.3)$; eight per cent $(4 / 50,8 \%)$ were less than 40 years of age. Two thirds $(33 / 50,66 \%)$ were within the age group 41 to 60 years of age. A quarter $(13 / 50,26 \%)$ were above 61 years of age (Table 1). patients with PRV were older than the other patients, while more females were seen with the ET group (Figure 1). JAK2 V617F was detected in the majority of $(35 / 50,70.0 \%) \mathrm{Ph}$-negative-MPDs cases, $(24 / 25,96 \%)$ in PRV $[\mathrm{M}=14, \mathrm{~F}=10],(10 / 13,76 \%)$ in ET $[\mathrm{M}=4, \mathrm{~F}=6]$, and $(1 / 1,100 \%)$ in $\mathrm{PMF}[\mathrm{M}=0, \mathrm{~F}=1]$. A minority $(4 / 50,8 \%)$ had wild-type of JAK2 (Table2). $J A K 2 V 617 F$ detected in two $(2 / 4,50 \%)$ cases within the age group $\leq 40,21(21 / 33,64 \%)$ cases within the age group 41 to 60 years of age, and $12(12 / 13,93 \%)$ cases were above 61 years of age. $B C R \_A B L$ fusion was detected in all (11/11, $100 \%$ ) cases of $\mathrm{CML}[\mathrm{M}=7, \mathrm{~F}=4]$ (Table2), one $(1 / 11,9 \%)$ case within the age group $\leq 40$, nine $(9 / 11,82 \%)$ cases within the age group 41 to 60 years of age, and one $(1 / 11,9 \%)$ case was above 61 years of age.

L1721W polymorphism of TET2 gene was seen in only one case $(1 / 50,2 \%)$, the case was ET male patient with $J A K 2 V 617 F$ mutation, he had 49 year old.(Table 3$)$. The results of screening $\mathrm{L} 1721 \mathrm{~W}$ polymorphism in TET2 gene, by using PCR-RFLP analysis are shown in Table 2.

Figure 2 display HaeIII digestion result on 3\% agarose gel, showing the positive L1721W sample.

Table 1. Demographic and clinical data including sex, age, and MPDs type of the study group.

\begin{tabular}{lll}
\hline Patients' characteristic & No. & Frequency \\
\hline Study group & 50 & 100 \\
Males & 26 & 52 \\
Females & 24 & 48 \\
Age group & & \\
$\leq 40$ & 4 & 8 \\
41 to 60 & 33 & 66 \\
Above 61 years & 13 & 26 \\
MPD types & & \\
& 25 & 50 \\
- PRV & M (14) & M 28 \\
& F (11) & F 22 \\
& 13 & 26 \\
- ET & M (5) & 10 \\
& F (8) & 16 \\
& 1 & 2 \\
- PMF & M (0) & 0 \\
& F (1) & 2 \\
- CML & 11 & 22 \\
& M (7) & 14 \\
\hline
\end{tabular}

MPD denotes myeloproliferative disorders, PRV polycythemia rupra vera, ET essential thrombocythemia, PMF primary myelofibrosis, CML chronic myeloid leukemia. Males $(\mathrm{M})>$ Females $(\mathrm{F})$, most of participants clustered at age group 41 to 60 .
Table 2. Clinical, gender, mutational status and L1721W data for MPD study patients.

\begin{tabular}{|c|c|c|c|c|}
\hline $\begin{array}{l}\text { Sample } \\
\text { number }\end{array}$ & $\begin{array}{l}\text { MPD } \\
\text { type }\end{array}$ & Gender & $\begin{array}{l}\text { Mutational status } \\
(J A K 2 V 617 F \& \\
\left.B C R \_A B L\right)\end{array}$ & $\begin{array}{l}\text { L1721W } \\
\text { Polymorphism in } \\
\text { TET2 gene }\end{array}$ \\
\hline 1 & PRV & $\mathrm{F}$ & $J A K 2 V 617 F$ & -ve/wt \\
\hline 2 & ET & $\mathrm{F}$ & $J A K 2 V 617 F$ & -ve/wt \\
\hline 3 & ET & $\mathrm{F}$ & $J A K 2 \mathrm{WT}$ & -ve/wt \\
\hline 4 & PRV & M & $J A K 2 V 617 F$ & -ve/wt \\
\hline 5 & PRV & M & $J A K 2 V 617 F$ & -ve/wt \\
\hline 6 & CML & $\mathrm{F}$ & $B C R \_A B L+v e$ & -ve/wt \\
\hline 7 & ET & M & $J A K 2 V 617 F$ & -ve/wt \\
\hline 8 & PRV & $\mathrm{F}$ & $J A K 2 V 617 F$ & -ve/wt \\
\hline 9 & CML & M & $B C R \_A B L+v e$ & -ve/wt \\
\hline 10 & PRV & M & $J A K 2 V 617 F$ & -ve/wt \\
\hline 11 & ET & $\mathrm{F}$ & $J A K 2 V 617 F$ & -ve/wt \\
\hline 12 & PRV & M & $J A K 2 V 617 F$ & -ve/wt \\
\hline 13 & PRV & $\mathrm{F}$ & $J A K 2 V 617 F$ & -ve/wt \\
\hline 14 & PRV & $\mathrm{F}$ & $J A K 2 V 617 F$ & -ve/wt \\
\hline 15 & CML & M & $B C R \_A B L+v e$ & -ve/wt \\
\hline 16 & ET & M & $J A K 2 V 617 F$ & -ve/wt \\
\hline 17 & PRV & M & $J A K 2 V 617 F$ & -ve/wt \\
\hline 18 & PRV & M & $J A K 2 V 617 F$ & -ve/wt \\
\hline 19 & ET & $\mathrm{F}$ & $J A K 2 \mathrm{WT}$ & -ve/wt \\
\hline 20 & PMF & $\mathrm{F}$ & $J A K 2 V 617 F$ & -ve/wt \\
\hline 21 & PRV & M & $J A K 2 V 617 F$ & -ve/wt \\
\hline 22 & CML & M & $B C R \_A B L+v e$ & -ve/wt \\
\hline 23 & ET & $\mathrm{F}$ & $J A K 2 V 617 F$ & -ve/wt \\
\hline 24 & PRV & F & $J A K 2 V 617 F$ & -ve/wt \\
\hline 25 & CML & $\mathrm{F}$ & $B C R \_A B L+v e$ & -ve/wt \\
\hline 26 & CML & $\mathrm{F}$ & $B C R \_A B L+v e$ & -ve/wt \\
\hline 27 & CML & $\mathrm{F}$ & $B C R \_A B L+v e$ & -ve/wt \\
\hline 28 & PRV & M & $J A K 2 V 617 F$ & -ve/wt \\
\hline 29 & CML & M & $B C R \_A B L+v e$ & -ve/wt \\
\hline 30 & PRV & M & $J A K 2 V 617 F$ & -ve/wt \\
\hline 31 & ET & M & $J A K 2 V 617 F$ & +ve L1721W \\
\hline 32 & PRV & $\mathrm{F}$ & $J A K 2 V 617 F$ & -ve/wt \\
\hline 33 & ET & $\mathrm{F}$ & $J A K 2 V 617 F$ & -ve/wt \\
\hline 34 & PRV & M & $J A K 2 V 617 F$ & -ve/wt \\
\hline 35 & PRV & M & $J A K 2 V 617 F$ & -ve/wt \\
\hline 36 & ET & $\mathrm{F}$ & $J A K 2 V 617 F$ & -ve/wt \\
\hline 37 & PRV & M & $J A K 2 V 617 F$ & -ve/wt \\
\hline 38 & CML & M & $B C R \_A B L+v e$ & -ve/wt \\
\hline 39 & ET & M & $J A K 2 \mathrm{WT}$ & -ve/wt \\
\hline 40 & CML & M & $B C R \_A B L+v e$ & -ve/wt \\
\hline 41 & PRV & $\mathrm{F}$ & $J A K 2 V 617 F$ & -ve/wt \\
\hline 42 & PRV & $\mathrm{F}$ & $J A K 2 V 617 F$ & -ve/wt \\
\hline 43 & ET & M & $J A K 2 V 617 F$ & -ve/wt \\
\hline 44 & PRV & M & $J A K 2 V 617 F$ & -ve/wt \\
\hline 45 & PRV & $\mathrm{F}$ & $J A K 2 V 617 F$ & -ve/wt \\
\hline 46 & PRV & $\mathrm{F}$ & $J A K 2 \mathrm{WT}$ & -ve/wt \\
\hline 47 & PRV & M & $J A K 2 V 617 F$ & -ve/wt \\
\hline 48 & PRV & $\mathrm{F}$ & $J A K 2 V 617 F$ & -ve/wt \\
\hline 49 & ET & $\mathrm{F}$ & $J A K 2 V 617 F$ & -ve/wt \\
\hline 50 & CML & M & $B C R \_A B L+v e$ & -ve/wt \\
\hline
\end{tabular}

Patient No. 31 had $L 1721 \mathrm{~W}$ polymorphism. MPD denotes myeloproliferative disorders, PRV polycythemia rupra vera, ET essential thrombocythemia, PMF primary myelofibrosis, CML chronic myeloid leukemia, $\mathrm{M}$ male, $\mathrm{F}$ female, $B C R \_A B L$ breakpoint cluster region_v-abl Abelson murine leukemia viral oncogene homolog 1, WT wild type (i.e., negative for $J A K 2 V 617 F$ ). 
52 Anas Abdelrahman Ibrahim and Eltahir Awad Gasim Khalil: Frequency of $L 1721 \mathrm{~W}$ Polymorphism in TET2 Gene Among a Cohort of Sudanese Patients with Myeloproliferative Disorders: Possible Roles in Pathogenicity and Leukemic Transformation

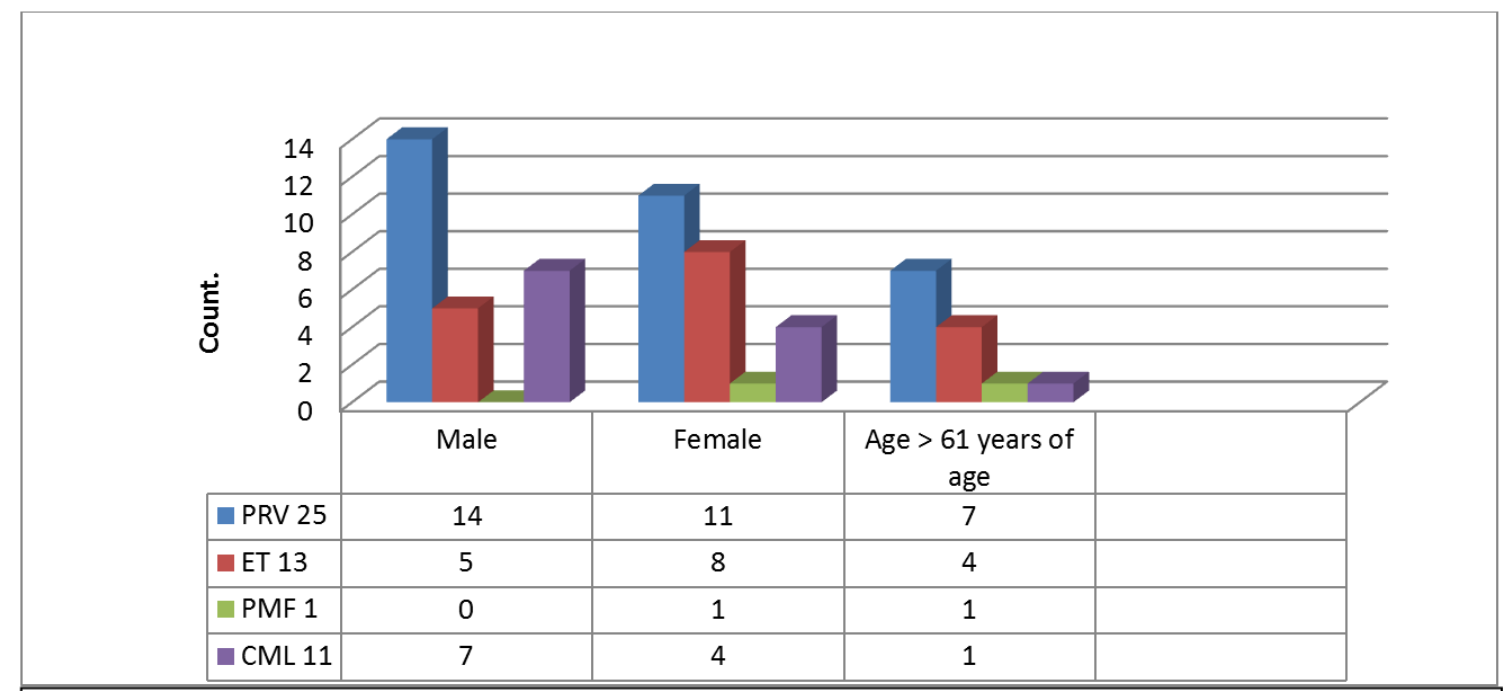

Figure 1. MPD types distribution among gender and elderly.

MPD denotes myeloproliferative disorders, PRV polycythemia rupra vera, ET essential thrombocythemia, PMF primary myelofibrosis, CML chronic myeloid leukemia. 7 PRV cases found in elderly ( $>61$ years of age), 8\13 of ET cases are females.

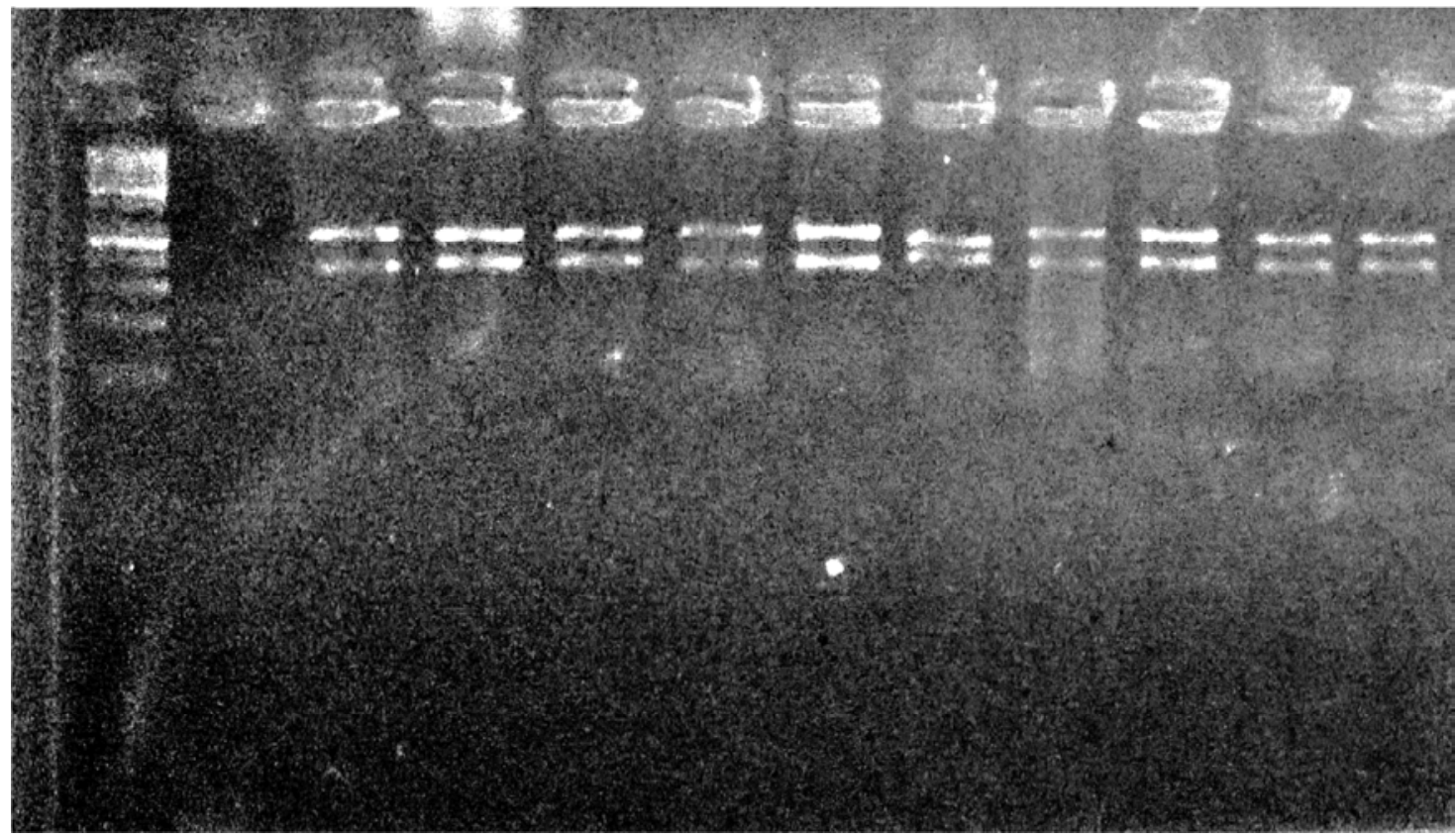

Figure 2. HaelII digestion result on 3\% agarose gel.

50 bp DNA ladder, negative control, and 10 samples were loaded. All samples (except No. 6) show two bands (267 \& 196 bp), sample No. 6 shows two bands with size $230 \& 196$ bp.

Table 3. Frequency of L1721W polymorphism in TET2 gene among 50 MPD Sudanese patients.

\begin{tabular}{llllll}
\hline RFLP result & Frequency & Percent & Cum. Percent & Exact 95\% LCL & Exact 95\% LCL \\
\hline L1721W + ve & 1 & $2.00 \%$ & $2.00 \%$ & $0.05 \%$ & $10.65 \%$ \\
-velwt & 49 & $98.00 \%$ & $100.00 \%$ & $89.35 \%$ & $99.95 \%$ \\
TOTAL & 50 & $100.00 \%$ & $100.00 \%$ & & \\
\hline
\end{tabular}

$L 1721 \mathrm{~W}$ detected in 1 case from 50 cases, Frequency, percentages, 95\% confidence interval (Cl) lower and 95\% Cl Upper for both $L 1721 \mathrm{~W}$ and wild-type (wt)

\section{Conclusion}

From the results of the present study, it can be concluded that the apparently low frequency of $L 1721 \mathrm{~W}$ polymorphism in this cohort of Sudanese MPD patients may have been due to the small sample size that is low to allow making 
statistically valid conclusions. But still it can be inferred that this mutation plays little of no role in the pathogenesis. It role in myeloid transformation needs further studies on MPD patients with transformation. Larger studies including an adequate number of TET2-mutated patients are needed to properly assess not only the prognostic relevance of mutant TET2 by itself, but also its potential prognostic interaction with other MPD-associated molecular markers. However, the whole literature on TET2 variants is quite small and more work is needed.

\section{References}

[1] Dameshek W. Some speculations on the myeloproliferative syndromes. Blood. 1951; 6(4): 372-375.

[2] Faderl S, Talpaz M, Estrov Z, O’Brien S, Kurzrock R, Kantarjian HM (1999). The biology of chronic myeloid leukemia. New England Journal of Medicine 341: 164-172.

[3] Grimwade D, Walker H, Harrison G, Oliver F, Chatters S, Harrison CJ, Wheatley K, Burnett AK, Goldstone AH. The predictive value of hierarchical cytogenetic classification in older adults with acute myeloid leukemia (AML): analysis of 1065 patients entered into the United Kingdom Medical Research Council AML11 trial. Blood. 2001; 98(5): 13121320 .

[4] Larson RA. Is secondary leukemia an independent poor prognostic factor in acute myeloid leukemia. Best Pract Res Clin Haematol.2007; 20(1): 29-37.

[5] Levine RL, Wadleigh M, Cools J, Ebert BL, Wernig G, Huntly BJ, Boggon TJ, Wlodarska I, Clark JJ, Moore S, Adelsperger J, Koo S, Lee JC, Gabriel S, Mercher T, D'Andrea A, Fröhling S, Döhner K, Marynen P, Vandenberghe P, Mesa RA, Tefferi A, Griffin JD, Eck MJ, Sellers WR, Meyerson M, Golub TR, Lee SJ, Gilliland DG. Activating mutation in the tyrosine kinase JAK2 in polycythemia vera, essential thrombocythemia, and myeloid metaplasia with myelofibrosis. Cancer Cell. 2005; 7(4): 387-397.

[6] Kralovics R, Passamonti F, Buser AS, Teo SS, Tiedt R, Passweg JR, Tichelli A, Cazzola M, Skoda RC. A gain-offunction mutation of JAK2 in myeloproliferative disorders. $N$ Engl J Med. 2005; 352(17): 1779-1790.

[7] Abdel-Wahab O, Mullally A, Hedvat C, Garcia-Manero G, Patel J, Wadleigh M, Malinge S, Yao J, Kilpivaara O, Bhat R, Huberman K, Thomas S, Dolgalev I, Heguy A, Paietta E, Le Beau MM, Beran M, Tallman MS, Ebert BL, Kantarjian HM, Stone RM, Gilliland DG, Crispino JD, Levine RL. Genetic characterization of TET1, TET2, and TET3 alterations in myeloid malignancies. Blood. 2009; 114(1): 144-147.

[8] Tahiliani M, Koh KP, Shen Y, Pastor WA, Bandukwala H, Brudno Y, Agarwal S, Iyer LM, Liu DR, Aravind L, Rao A. Conversion of 5-methylcytosine to 5-hydroxymethylcytosine in mammalian DNA by MLL partner TET1. Science. 2009; 324(5929): 930-5.

[9] Pastor, W. A., Aravind, L. \& Rao, A. TETonic shift: biological roles of TET proteins in DNA demethylation and transcription. Nat. Rev. Mol. Cell Biol. 14, 341-356 (2013).
[10] Spruijt CG, Gnerlich F, Smits AH, Pfaffeneder T, Jansen PW, Bauer C, Münzel M, Wagner M, Müller M, Khan F, Eberl HC, Mensinga A, Brinkman AB, Lephikov K, Müller U, Walter J, Boelens R, van Ingen H, Leonhardt H, Carell T, Vermeulen M. Dynamic readers for 5-(hydroxy) methylcytosine and its oxidized derivatives. Cell 152, 1146-1159 (2013).

[11] Wu, H. \& Zhang, Y. Reversing DNA methylation: mechanisms, genomics, and biological functions. Cell 156, 45-68 (2014).

[12] Delhommeau F, Dupont S, Della Valle V, James C, Trannoy S, Massé A, Kosmider O, Le Couedic JP, Robert F, Alberdi A, Lécluse Y, Plo I, Dreyfus FJ, Marzac C, Casadevall N, Lacombe C, Romana SP, Dessen P, Soulier J, Viguié F, Fontenay M, Vainchenker W, Bernard OA. Mutation in TET2 in myeloid cancers. N Engl J Med. 2009; 360(22): 2289-2301.

[13] An J, González-Avalos E, Chawla A, Jeong M, LópezMoyado IF, Li W, Goodell MA, Chavez L, Ko M, Rao A. Acute loss of TETfunction results in aggressive myeloid cancer in mice. Nature Communications. 2015; 6: 10071. doi: 10.1038/ncomms 10071 .

[14] Langemeijer SMC, Kuiper RP, Berends M, Knops R, Aslanyan MG, Massop M, Stevens-Linders E, Van Hoogen P, Van Kessel AG, Raymakers RAP, Kamping EJ, Verhoef GE, Verburgh E, Hagemeijer A, Vandenberghe P, De Witte T, Van Der Reijden BA, Jansen JH. Acquired mutations in TET2 are common in myelodysplastic syndromes. Nature Genetics. 41(7): 838-842.

[15] Nibourel O, Kosmider O, Cheok M, Boissel N, Renneville A, Philippe N, Dombret H, Dreyfus F, Quesnel B, Geffroy S, Quentin S, Roche-Lestienne C, Cayuela J, Roumier C, Fenaux P, Vainchenker W, Bernard OA, Soulier J, Fontenay M, Preudhomme C. Incidence and prognostic value of TET2 alterations in de novo acute myeloid leukemia achieving complete remission. Blood. 116: 1132-1135.

[16] Martinez-Avilés L, Besses C, Alvarez-Larran, Torres E, Serrano S, Bellosillo B. TET2, ASXL1, IDH1, IDH2 and cCBL genes in JAK2- and MPL-negative myeloproliferative neoplasms. Annals of Hematology. 91: 533-541.

[17] Tefferi and J. M. Vardiman, "Classification and Diagnosis of Myeloproliferative Neoplasms: The 2008 World Health Organization Criteria and Point-of-Care Diagnostic Algorithms," Leukemia, Vol. 22, 2008, pp. 14-22.

[18] Vardiman JW, Harris NL, Brunning RD. The World Health Organization (WHO) classification of the myeloid neoplasms. Blood. 2002; 100(7): 2292-2302.

[19] Pardanani A, Reeder TL, Kimlinger TK, Baek JY, Li CY, Butterfield JH, Tefferi A. Flt-3 and c-kit mutation studies in a spectrum of chronic myeloid disorders including systemic mast cell disease. Leuk Res. 2003; 27:739-742.

[20] Baxter EJ, Scott LM, Campbell PJ, East C, Fourouclas N, Swanton S, Vassiliou GS, Bench AJ, Boyd EM, Curtin N, Scott MA, Erber WN. Acquired mutation of the tyrosine kinase JAK2 in human myeloproliferative disorders. Lancet. 2005; 365(9464): 1054-1061. 22: 756-761.

[21] G. W. Montgomerya \& J. A. Sisea. Extraction of DNA from sheep white blood cells. New Zealand Journal of Agricultural Research. 2012; 33; 437-441. 